\title{
Comparison of Growth and Yield Performance of Okra Crop under Mulching Systems
}

\author{
P. Akhila ${ }^{\dagger}$, S. Meena ${ }^{\dagger}$, CH. N. V. Srinivasa Rao $^{\dagger}$, D. Kumar ${ }^{\dagger}$, B. Gopi ${ }^{\dagger}$ and V. Tejaswini ${ }^{\dagger}$ \\ Department of Agricultural Engineering, Vikas College of Engineering and Technology, \\ Nunna, Vijayawada, Andhra Pradesh, India \\ ${ }^{\dagger}$ All Authors Contributed equally to this manuscript
}

\begin{tabular}{|l|}
\hline K e y w o r d s \\
Mulching, Control, \\
$\begin{array}{l}\text { Drip irrigation, Okra, } \\
\text { Growth } \\
\text { characteristics, Yield }\end{array}$ \\
\hline Article Info \\
\hline $\begin{array}{l}\text { Accepted: } \\
\text { 26 September } 2018 \\
\text { Available Online: } \\
\text { 10 October } 2018\end{array}$ \\
\hline
\end{tabular}

\section{Introduction}

Okra (Abelmoschus esculents L.) is one of the most important vegetable crops grown throughout the tropics and subtropics. The nutritional value of $100 \mathrm{~g}$ of edible portion of okra contains about $1.9 \mathrm{~g}$ protein, $0.2 \mathrm{~g}$ fat, 6.4 $\mathrm{g}$ carbohydrate, $0.7 \mathrm{~g}$ minerals and $1.2 \mathrm{~g}$ fibre (Gopalan et al., 1989). Okra crop is grown
This study investigated the effects of mulching materials on yield and growth performance of Okra crop under drip irrigation. The treatments of the study comprised of two mulches (black polyethylene and coconut coir), control (without mulch) and under shade conditions. Initially, the plant height was more in under shade $(25.5 \mathrm{~cm})$ and least in control condition $(16 \mathrm{~cm})$. Difference in plant height was negligible in coir and plastic mulch. In flowering stage, the plant height was high in plastic mulch $(54 \mathrm{~cm})$ followed by coir, control and under shade $(44 \mathrm{~cm})$. During harvesting stage, maximum height was observed in plastic mulching $(111 \mathrm{~cm})$ and least was observed in under shade $(79 \mathrm{~cm})$ due to the fact that it provides all the required nutrients for germination but doesn't support it for entire growth. The difference in number of leaves was also followed the same trend like plant height in different treatments. The soil temperature differences were negligible when compared. However, in the initial and flowering stages temperature was high in plastic mulching $\left(30^{\circ} \mathrm{C}\right)$ and least in under shade $\left(26^{\circ} \mathrm{C}\right)$. During the harvesting stage high temperatures were recorded in control and least in under shade. The soil moisture in initial stage was more in under shade and in flowering stage it was more in control. In harvesting stages, plastic mulching recorded with high soil moisture It was observed that highest yield was obtained for okra crop under black plastic mulch when compared to others. In plastic mulch, all the parameters showed higher growth rate and increased yield. The study concluded that yield obtained in plastic mulching was 50\% more when compared to others due to the fact that, it was less susceptible to infestation and weed growth. 
order to retain heat which is lost during the night. Application of mulch reduces bulk density, soil temperature and increases porosity, soil moisture content, $\mathrm{pH}$, organic matter, soil and leaf $\mathrm{N}, \mathrm{P}, \mathrm{K}, \mathrm{Ca}, \mathrm{Mg}$, pod yield and growth indices of okra when compared with the control (Adekiya. 2017). Mulching also decreases weed density and promotes crop growth (Sinkeviciena et al., 2009). Materials used as much includes coir, woodchips, paper, stones, plastic sheet, paddy straw etc.

Coconut fibre or coir, a natural waste product resulting from the processing of coconut, has become widely used by gardeners as a mulch, soil amendment and potting soil ingredient. The benefits of coir mulch includes renewability, water retention capacity, and improvement in soil fertility. Coconut coir is a solid organic manure that improves air circulation. It also stores water 6 times more than its volume and hence most widely used material in organic farming.

Plastic mulch is a product used as mulch in order to suppress weeds and conserve water in crop production and landscaping. Disposal of plastic mulch may an environmental problem, but recent technologies can provide for the recycling of used plastic mulch into viable plastic resins for re-use in the plastics manufacturing industry. In recent days, plastic mulch plays a key role in promoting vegetable production as it promotes growth and yield of the crop (Aniekwe, 2013). Plastic mulch is often used in conjunction with drip irrigation which is predominant in large-scale vegetable growing. There are many advantages when using plastic mulch in combination with drip irrigation such as minimizing fertilizer and nutrient losses, high water application efficiency, maintaining sufficient moisture within the root zone, reducing weed growth, reducing the risk of diseases and also improves crop quality. The disadvantages with this method include high initial cost, shorter life span and incorrect disposal of plastic sheet. Generally, the yield will be more under drip irrigation which may be due to optimum water utilization, increased uptake of nutrients (Bafna et al., 1993) and also due to maintaining excellent soil-water relationship in the root zone with higher oxygen concentration. With this background, a study was conducted to compare the growth and yield differences of okra crop under different types of mulching such as coir, polythene, and also without mulching (control).

\section{Materials and Method}

The present investigation, "Comparison of yield and growth performance of Okra crop under mulching systems" was carried out during the rabi season of 2017-2018 under the edaphic and climatic condition of Nunna (A.P). The materials and methods employed in the study were discussed briefly in this chapter.

\section{Experimental site}

The study was conducted in the experimental field of Vikas College of Engineering and Technology during the period 2017-18 from January to March under the edaphic and climatic condition of Nunna (A.P), with an area of $396 \mathrm{~m}^{2}(22 \times 18 \mathrm{~m})$ in order to analyse the growth characteristics and yield differences of okra crop grown under various mulching materials, control condition and also under shade. The research farm was located on $1662^{\prime} 78^{\prime \prime} \mathrm{N}$ latitude and $8067^{\prime} 40^{\prime \prime} \mathrm{E}$ longitude at an altitude of about $29 \mathrm{~m}$ above sea level. The soil in the study area was red sandy loam texture.

\section{Land preparation}

After clearing the land, primary tillage operations were done with a tractor drawn 
rigid tyne cultivator for the initial loosening of the soil and for removing the weeds. After one week, land was again tilled with a tractor drawn rotavator in order to mix the soil thoroughly. On $8^{\text {th }}$ January, 2018 the land was marked appropriately for the preparation of seed bed. The following day seed bed was prepared manually with shovel of dimensions $22 \times 1.0 \times 0.15 \mathrm{~m}$ for sowing. The experimental field was again divided into 4 plots namely A (coconut coir), S (plastic mulch), M (control), $\mathrm{K}$ (under shade with plastic mulch).

In between each plot $1.0 \mathrm{~m}$ spacing was provided. The bed to bed spacing was $0.4 \mathrm{~m}$, whereas plant-plant $0.4 \mathrm{~m}$ and row-row spacing was $0.6 \mathrm{~m}$ respectively. The layout of the experimental plot was shown in figure 1 .

\section{Application of water}

Time of operation of drip system for different treatments was calculated and based on this drip system was operated daily as per the irrigation schedule (1.2 litres/hour). Initially 0.6 litres/30min was applied.

\section{Components of drip system}

A drip irrigation system essentially consists of mainline, sub mains, lateral, drippers, filters and other small fittings and accessories like valves, pressure regulators, pressure gauge, fertilizer application components etc.

\section{Main line}

Main line for the experimental field was shown in figure 2 . The main line conveys the water from filtration system to the sub main and is normally made of rigid PVC pipes in order to minimize corrosion and clogging. Usually they are placed below the ground i.e. 60 to $90 \mathrm{~cm}$ (2 to $3 \mathrm{ft}$ ) in order to avoid interference with cultivation practices. Generally, their diameter is selected based on the system flow capacity. In present study, the pipe of $75 \mathrm{~cm}$ diameter $(\varnothing)$ was used.

\section{Sub main}

The Sub main conveys the water from main line to the laterals which are also buried in ground below 2 to $2.5 \mathrm{ft}$ and made of rigid PVC. The diameter of Sub main used in this study was $63 \mathrm{~cm}$ which was shown in figure 3 .

\section{Laterals}

Laterals are small diameter flexible pipes which are made of low density polyethylene (LDP) or linear low density polyethylene (LLDPE) and are available with $12 \mathrm{~mm}$, $16 \mathrm{~mm}$, and $20 \mathrm{~mm}$ size. Their colour is generally black in order to avoid the algae growth and effect of ultra- violet radiation. In present study, $16 \mathrm{~mm}$ dia lateral was used with a length of $616 \mathrm{~m}$.

\section{Emitters or drippers}

It is the main component of drip irrigation system which discharges water from lateral to the soil i.e. to the plants. They are generally made of plastic, such as polythene or polypropylene.

\section{Grommet and take-off}

These are used to connect lateral to the Sub main and can also acts as a seal. A hole is punched with hand drill of predetermined size in sub main and grommet is fixed into the hole. Take off is pressed into the hole. For the experiment $16 \mathrm{~mm}$ diameter grommets were used.

\section{End caps (End Sets)}

These are used to close the lateral ends, Sub main ends or mainline ends. Generally, sub mains and mains are preferably provided with 
flush valve which provides convenience for flushing. For this experiment, $16 \mathrm{~mm}$ diameter end caps were used as shown in figure 4 .

\section{Application of mulch}

Two types of mulches such as coconut coir and black polyethylene sheet $(25 \mu)$ were applied on the surface of 4 beds each and another 4 beds left without mulch (control) which were shown in figures 5 and 6 .

\section{Sowing of seeds}

Sowing was done on $22^{\text {nd }}$ of January 2018. Okra seed (Variety - chiranjeevi f1) was sown with a spacing of $40 \times 60 \mathrm{~cm}$ in paired with drip irrigation system.

Total number of seeds taken for experiment was 2600 .

\section{Soil moisture and temperature measurements}

Soil samples were collected randomly from around the field. Moisture was mwasured by oven dry method for 24 hours at $105^{\circ} \mathrm{C}$ using the following formula

Soil moisture on wet basis = $\frac{\text { Weight of moist sample-Weight of oven dry sample }}{\text { Weight of oven dry sample }} \times 100$

Soil temperature was measured in different stages in different treatments by using soil thermometer.

\section{Germination percentage}

Seed germination was recorded regularly upto the end of germination stage. Observations were made and a sample formula was used in calculating the germination percentage.

Total germination $(\%)=($ Total seeds germinated/total no. of seeds planted) $\times 100$
At the initial stage of seedling, the problem of insects was very high which results in severe loss of seedlings. In order to prevent attack of insects on the crop, an insecticide "Targa super" was sprayed at the rate of $98 \mathrm{ml} / 20$ litres of water. After a few days, a mixture of urea and potash was given to plants for their better growth. After twenty five days of sowing i.e., on $17^{\text {th }}$ February 2018, the effect of leaf eating insects increased rapidly comparing to initial stages. To control this situation, an insecticide "Coragen" was sprayed at a rate of $10 \mathrm{ml} / 20$ litres of water. On $27^{\text {th }}$ February 2018, it was observed that some of the leaves were subjected to wilting. So, in order to terminate this process "Bio-Jodi", a pesticide of 100 grams per 20 litres of water was sprayed.

\section{Results and Discussion}

The results obtained from the study and a brief discussion about the results was explained elaborately in this section.

\section{Germination percentage}

The initial germination percentage was more in under shade $(96 \%)$, followed by coir and control $(88 \%)$ and black plastic mulch $(77 \%)$. After 10 days, the germination percentage was maximum in black plastic mulching and least in coir.

\section{Growth characteristics}

The following growth characteristics were studied and subsequent observations were recorded on 30, 60 days after sowing and harvest stage

\section{Plant height (cm)}

The plant height was measured by metre scale from ground level to the tip of the flag leaf at harvest. Observed plant heights for five randomly selected plants were shown in figure 7. 
Fig.1 Layout of the field

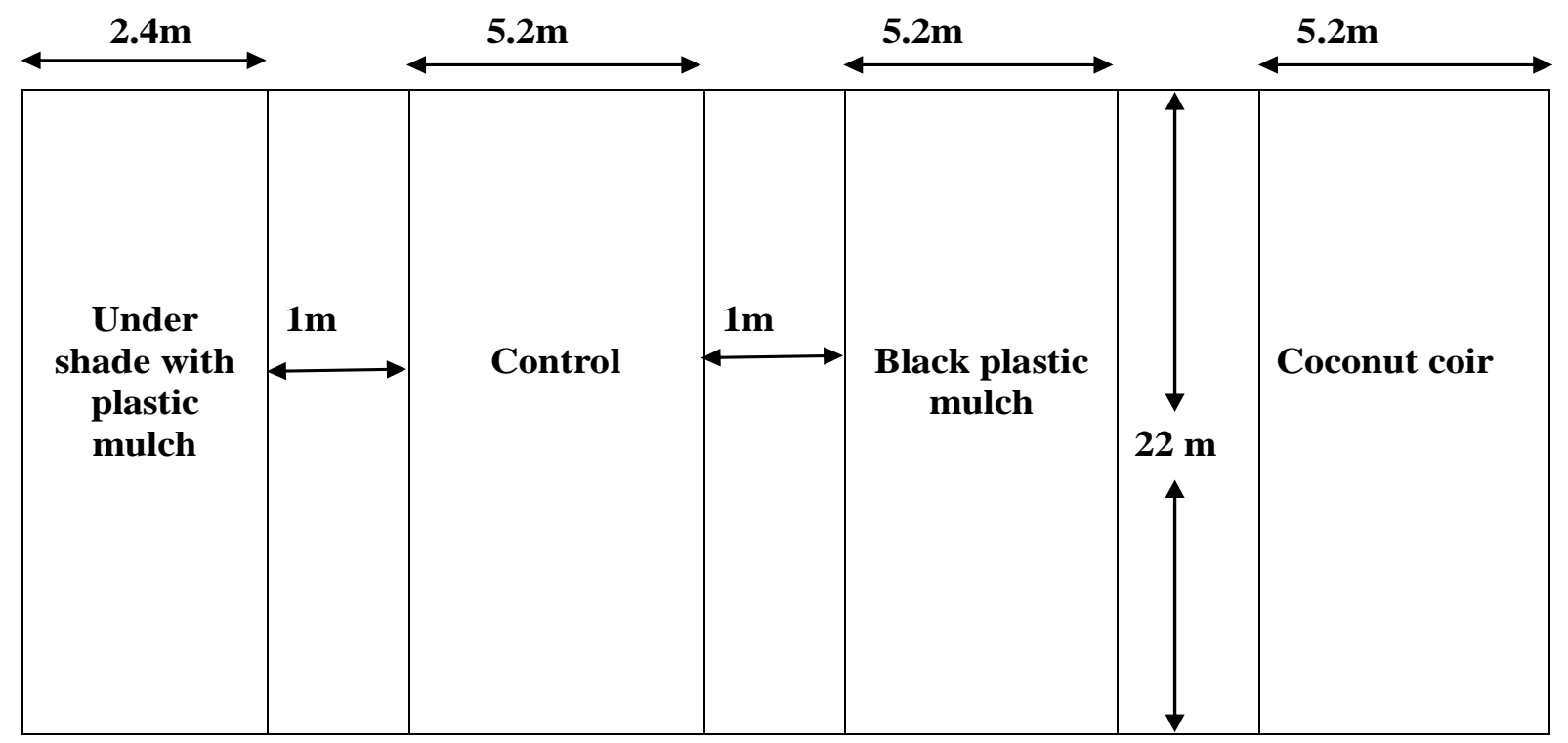

Fig.2 Main line

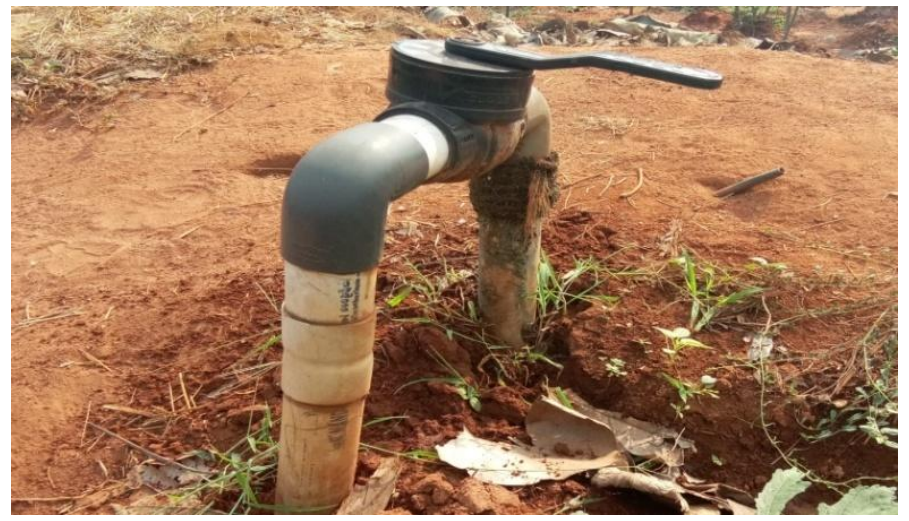

Fig.3 Sub main

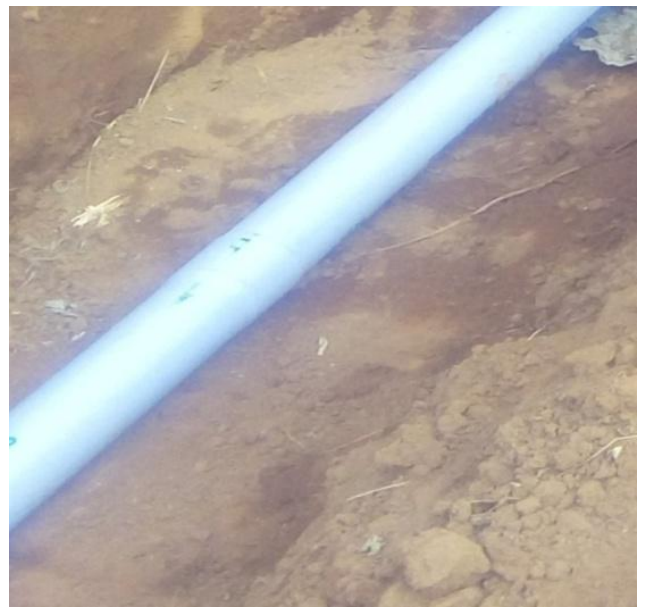


Fig.4 End caps
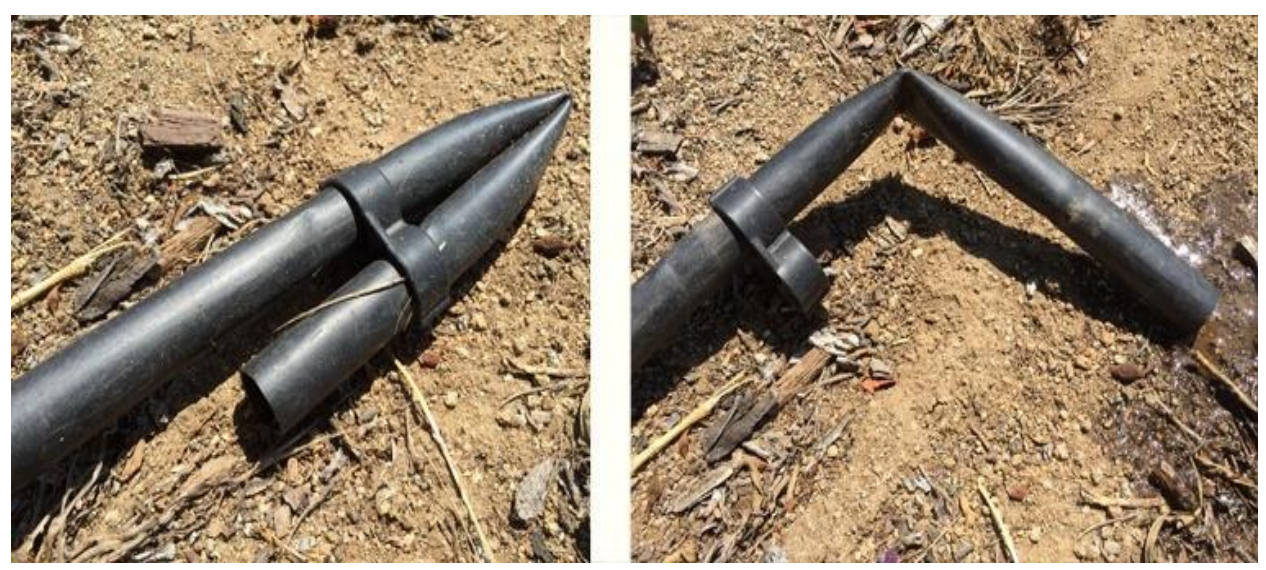

Fig.5 Application of coconut coir mulch in the field

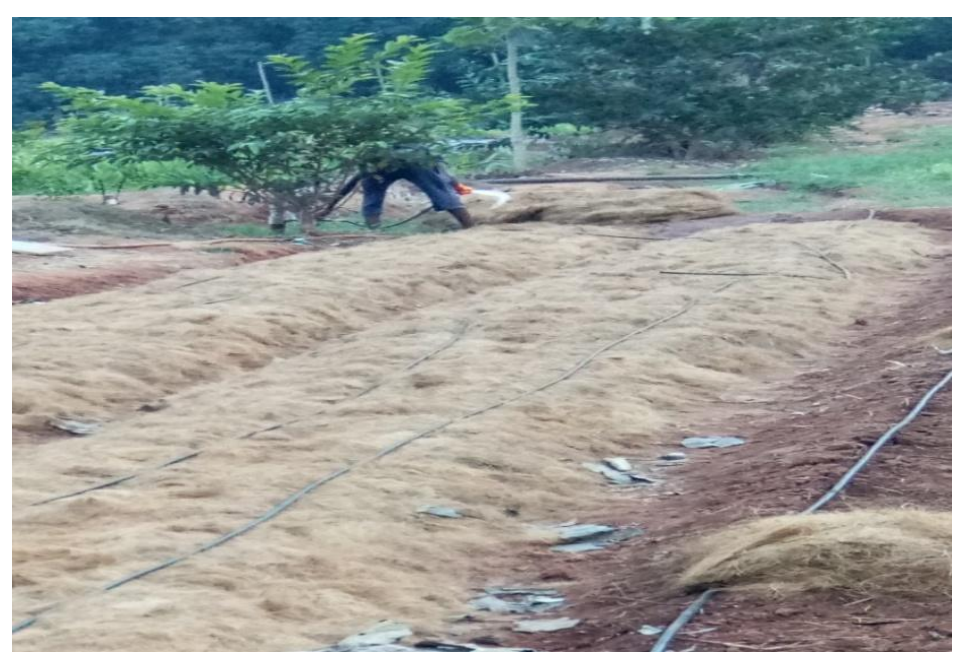

Fig.6 Application of black polyethylene mulch in the field

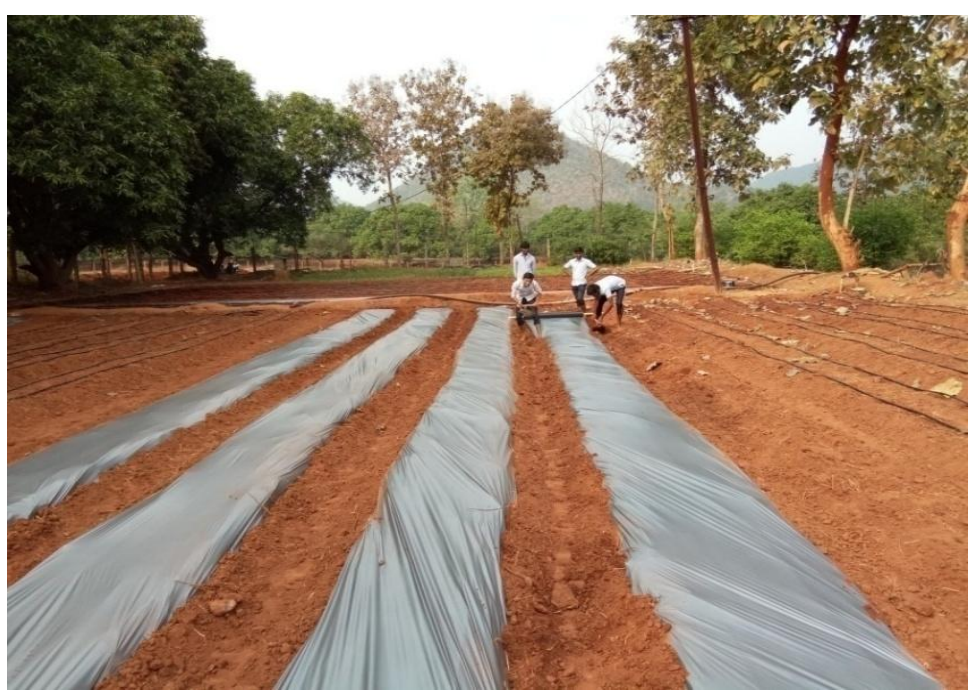


Fig.7 Plant height in different treatments (A-coconut coir, S-black polyethylene, M-control and K-under shade with plastic mulch)

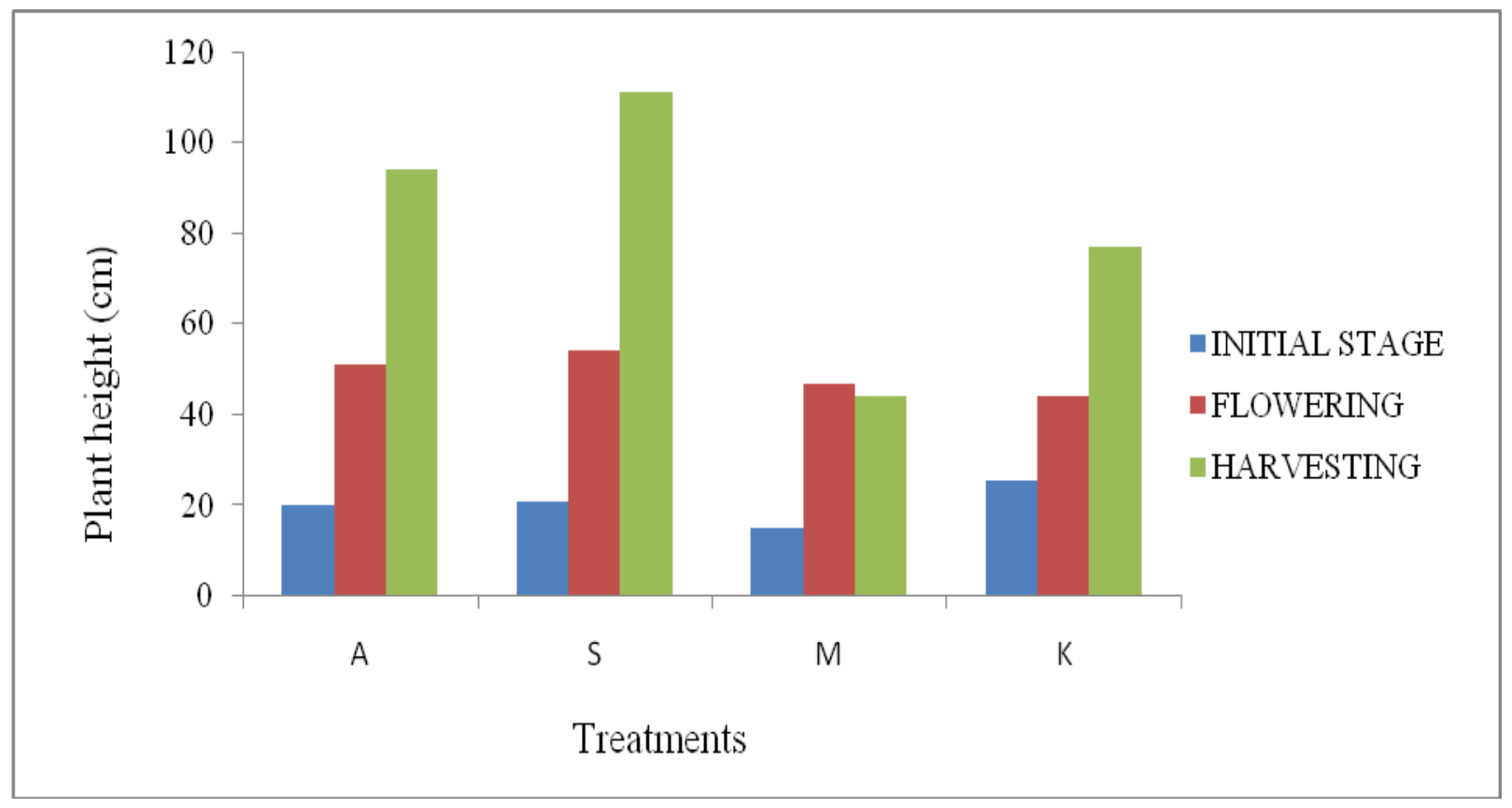

Fig.8 Number of leaves in different treatments (A-coconut coir, S-black polyethylene, M-control and K-under shade with plastic mulch)

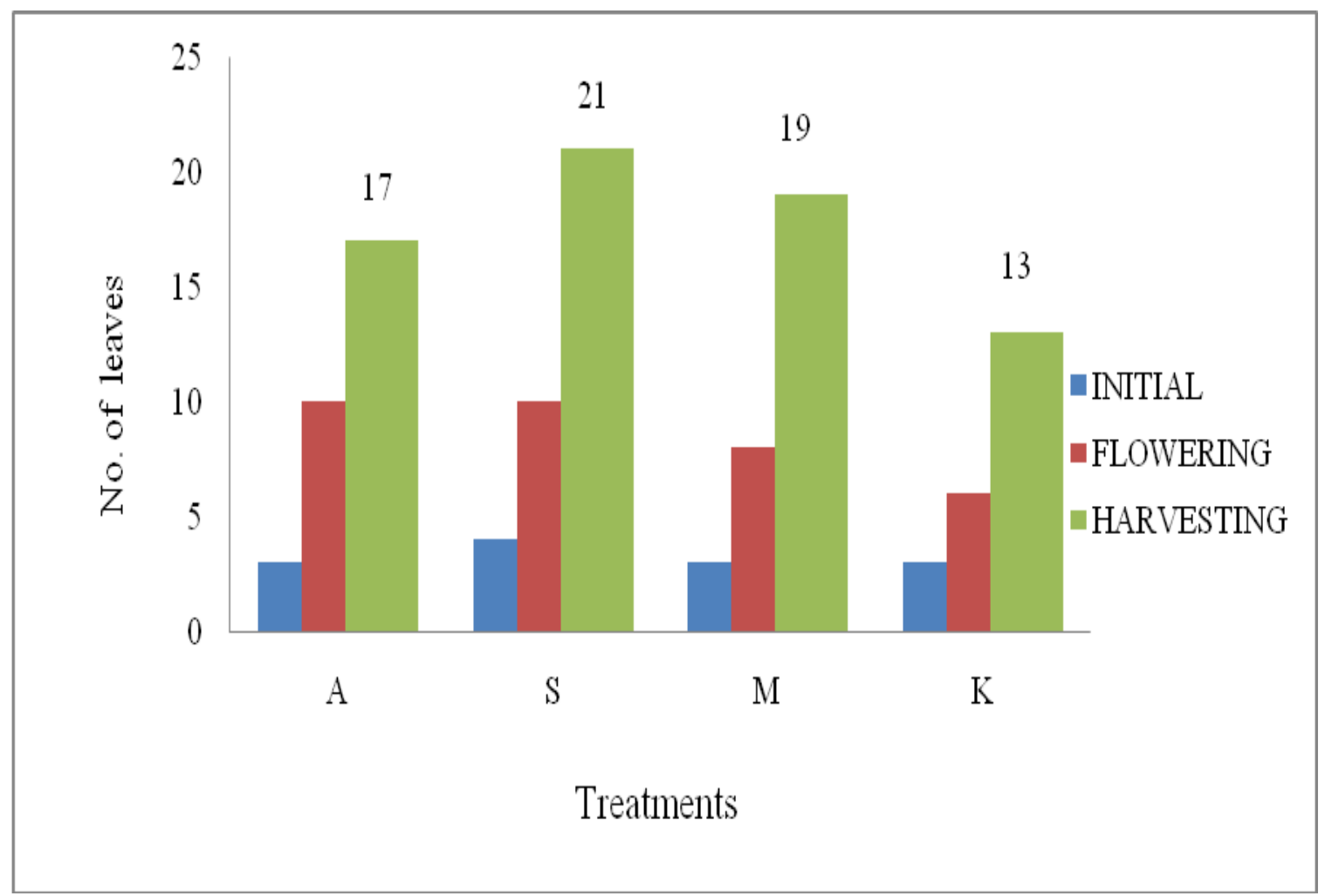


Fig.9 Average soil temperature in different treatments (A-coconut coir, S-black polyethylene, Mcontrol and K-under shade with plastic mulch)

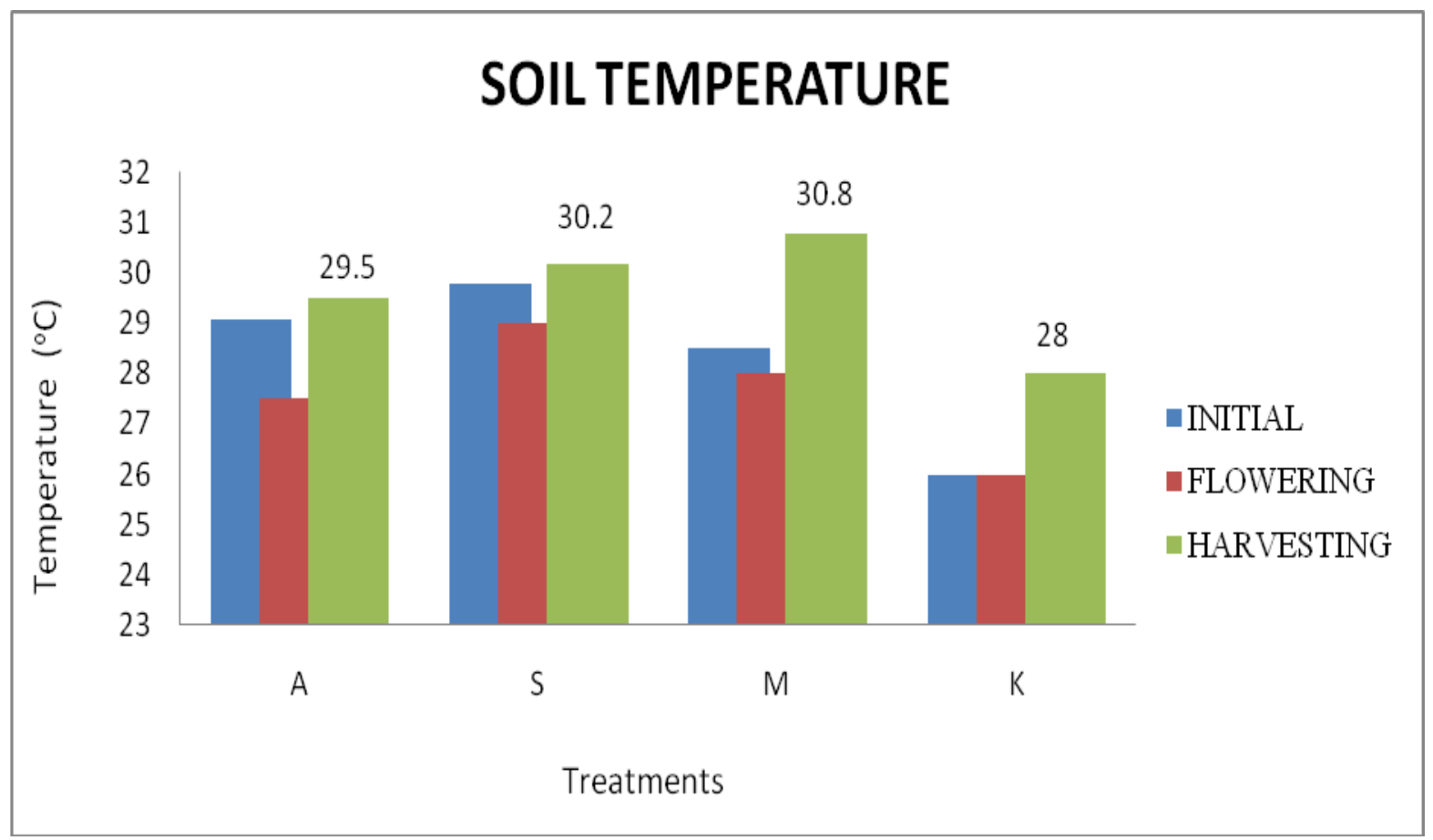

Fig.10 Average soil moisture in different treatments (A-coconut coir, S-black polyethylene, Mcontrol and K-under shade with plastic mulch)

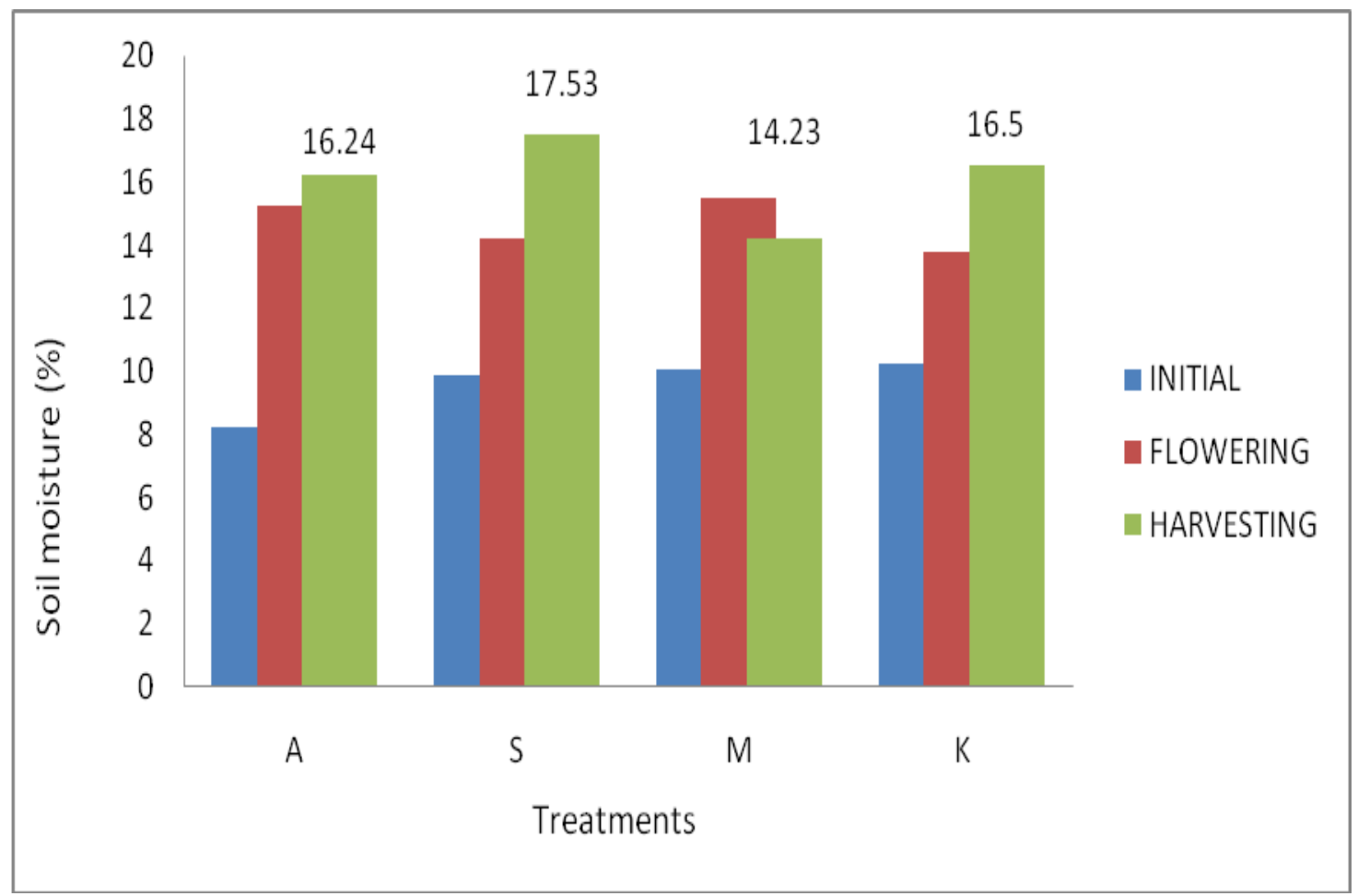


Fig.11 Yield in different harvestings under different treatments (A-coconut coir, S-black polyethylene, M-control and K-under shade with plastic mulch)

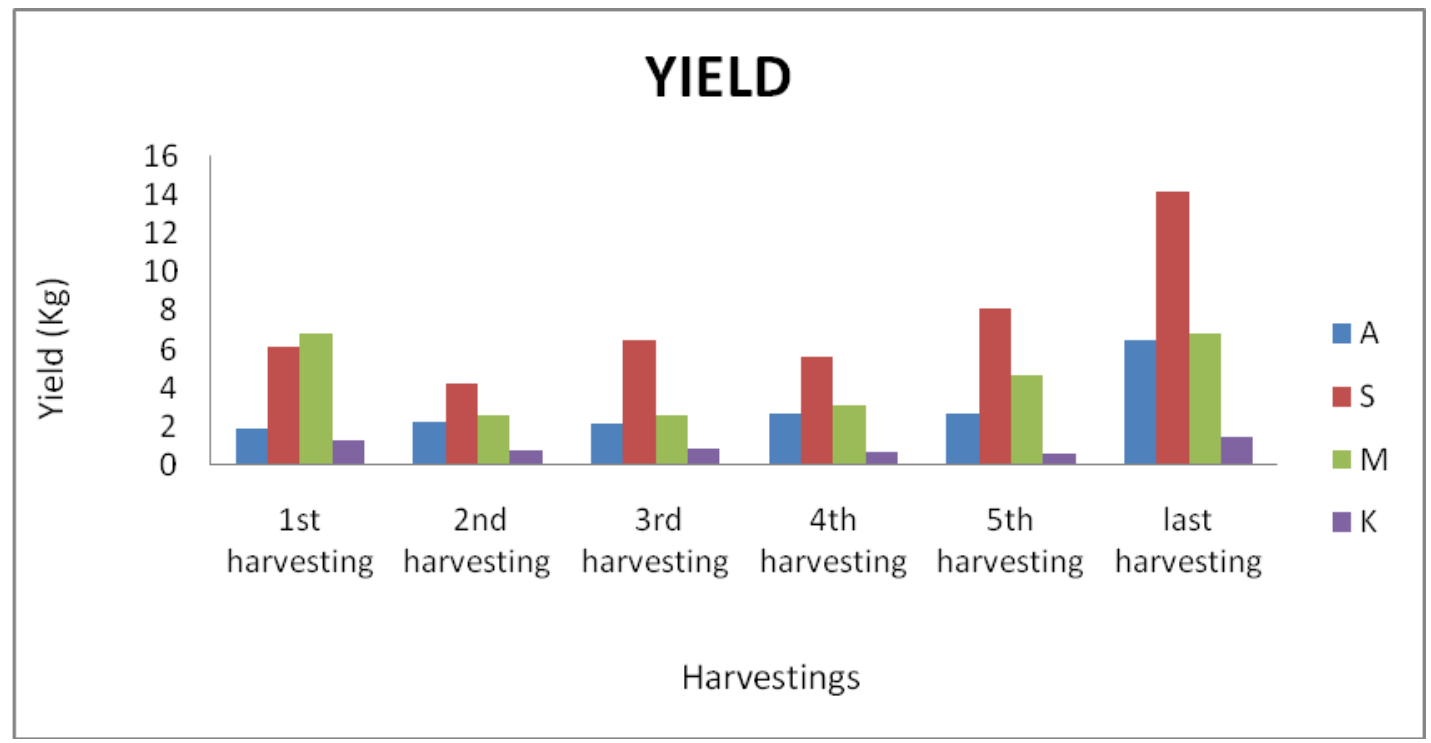

\section{Number of leaves per plant}

The number of leaves per plant of the selected five tagged plants from each plot was counted, their average was calculated and shown in figure 8 . In the figure, it was shown that in the initial stage the plant height was more in under shade and least in control. In flowering stage it was maximum in plastic mulch and least in under shade. In harvesting stage the plant height was maximum in plastic mulch and least in control.

The number of leaves observed in initial stage was more in black plastic mulch followed by control, coir and under shade. In the flowering stage, this was more in plastic mulch and coir. The least was observed in under shade. During harvesting stage, the number of leaves was maximum in black plastic mulch and least in under shade. All the readings are measured with $30 \mathrm{~cm}$ mild steel scale.

A week after sowing, the weeding process was done manually once in every week. Overall least weeds were observed in plastic mulch and under shade followed by coir.
Maximum weeds were observed in control which effects the both growth and yield parameters.

\section{Soil temperature and moisture content}

Highest temperature difference i.e., 2.5 to $3.5^{\circ} \mathrm{C}$ were noticed between plots without mulch and those mulched with coconut coir which shows that organic mulches will significantly decreases soil temperature. Soil temperature in different treatments was shown in figure 9. The figure 9 shows that mulched plots maintains higher soil moisture content during the entire experimental period when compared to control plots. Among mulched plots, plots with black polyethylene show more and optimum moisture content which is an important factor for crops (Fig. 10).

\section{Yield characteristics}

A digital weighing machine was used for measuring the weight of harvested okra. Totally Six harvestings were conducted manually and it was observed that, in the $1^{\text {st }}$ harvesting both plastic mulch and control 
were estimated to had same yield. From the $2^{\text {nd }}$ harvesting, the plastic mulch showed increased yield nearly double when compared to control. Yield in different treatments for different harvestings were shown in figure 11. The results obtained from the field study were carried out at Vikas College of Engineering and technology, Vijayawada, Andhra Pradesh from January to March 2018. The treatments comprised of coconut coir mulch, black polyethylene mulch, control and black plastic mulch in under shade. Initially, all the treatments showed some little deviation in growth performance, but finally during the harvesting stage, treatment with black polyethylene mulch showed increased growth parameters when compared to others. Similarly, weed suppression and yield was also observed more in black polyethylene mulch in comparison with others. In conclusion, black polyethylene sheet mulch maintains optimum soil moisture content and soil temperature throughout the experimental period and thus, had a high growth and yield performance. Therefore, for optimum growth and yield production of Okra crop under Nunna (Vijayawada, A.P), it is recommended to use black polyethylene mulch as an agronomic practice.

\section{References}

Adekiya, A.O., Agbede T. M., Aboyeji C. M. and Dunsin. O. 2017. Response of Okra (Abelmoschus esculents (L.) Moench) and Soil Properties of Different Mulch Materials in Different Cropping Season. Scientia Horticulturae. 21: 209-216.

Adekiya, A.O., Agbede, T.M., Aboyeji, C.M. and Dunsin, O. 2017. Response of Okra

Aniekwe N. L. 2015. Comparative Effects of Organic and Plastic Mulches on the Environment, Growth and Yield of Okra. International Journal of Science and Research. 4 (1): 1860-1863.

Bafna, A.M., Deftardar, S.Y., Khade, K.K., Patel, P.V. and Dhotre, R.S. 1993. Utilization of Nitrogen and Water by Tomato under Drip Irrigation System. Journal of Water Management. 1(1): 15.

Gopalan, Rama Sastri, B.V., and Balasubramanian, S.C.1989. "Nutritive value of Indian Foods."

Sinkeviciene, D., Jodaugienè, R., Pupalienè and Urbonienè, M. 2009. The Influence of Organic Mulches on Soil Properties and Crop Yield. Agronomy Research.7: 485-491.

\section{How to cite this article:}

Akhila, P., S. Meena, CH. N. V. Srinivasa Rao, D. Kumar, B. Gopi and Tejaswini, V. 2018. Comparison of Growth and Yield Performance of Okra Crop under Mulching Systems. Int.J.Curr.Microbiol.App.Sci. 7(10): 3670-3679. doi: https://doi.org/10.20546/ijcmas.2018.710.424 